\title{
The Role and Importance of the Energy Saving in Georgia
}

\author{
Demuri Chomakhidze $^{1 *}$, Omari Zivzivadze², Petre Kachkachishvili², Akaki Kiladze ${ }^{2}$ \\ ${ }^{1}$ Georgian Technical University, Tbilis, Georgia \\ ${ }^{2}$ Akaki Tsereteli State University, Kutaisi, Georgia \\ Email: *demurchomakhidze@yahoo.com
}

How to cite this paper: Chomakhidze, D. Zivzivadze, O., Kachkachishvili, P. and Kiladze, A. (2018) The Role and Importance of the Energy Saving in Georgia. Theoretical Economics Letters, 8, 1740-1745. https://doi.org/10.4236/tel.2018.810113

Received: January 30, 2018

Accepted: June 17, 2018

Published: June 20, 2018

Copyright (c) 2018 by authors and Scientific Research Publishing Inc. This work is licensed under the Creative Commons Attribution International License (CC BY 4.0).

http://creativecommons.org/licenses/by/4.0/

\begin{abstract}
The role and importance of the energy saving in the conditions of Georgia are analyzed in this article. Based on the specific materials, the impact of the public labor fruitfulness and energy saving is compared to the volume of the whole inside product (WIP). It is said, that the reduction of the energy volume of WIP on $1 \%$ is giving approximately the same and in separate years even more effect in the augment of the volume of the WIP, compared to the rising the public labor productivity in the same way. In reference to this, the level of the main macroeconomic indicators of the development of the Georgian economy and the dynamics for 2013-2016 is studied in this article.
\end{abstract}

\section{Keywords}

GPD, Energy Resources, Energy Volume, Energy Saving, Labor Productivity

\section{Introduction}

It is undoubtedly a long time truth that without the regime of the economy the society will not be able to control its limited resources. Economy is the essential condition in achievement of the agricultural business. It can be reached by the reduction of the losses, using the resource economizing technologies, high organization of the labor etc.

The problem is distinctively actual in the view of usage the energy resources. It is especially significant for those countries which have the shortage of these resources. Georgia is among them [1]. Our country is getting the most quantity of the energy resources (approximately 70\%) from the outer countries in order to provide the own economy. It is the whole amount of the consumed natural gas, oil and oil products main, and in the period of autumn-winter the significant part of the electro energy. The far distance transfers, despite its being ra- 
tional, are a burden for each enterprise and the whole economy of the country. For example in 2016 the local productivity of energy was 1376.3 tone conditional heating [1], and the total volume of used energy 4330.5 tone conditional heating. It means that the energy, produced by Georgia is a $31.7 \%$ of the total volume of used energy [2].

The expended reproductive intensive form is the organic character of the economic system of the society. It makes the objective precondition for the utilization of the resources rationally and effectively, in order to achieve the better final results.

It is known that from the intensive factor of the economic growth of the country, the increase of the labor productivity of the society is the most important. Its role in every areas of the development of life is immeasurable in the improvement of the material and cultural state of the members of the society. It undoubtedly represents the main source of the growth of the whole inside product (GPD) and makes a big opportunity for the increase of the life level, the reduction of the working time and the augment of the free time as well [3].

But is it enough or not for the successful implementation of the intensive course of the economic growth of the country only by achievement of the high tempus of the labor productivity growth, even when the whole addition of the product in the field is got at the expense of labor productivity augment? In our opinion, the answer to this question cannot be positive unilaterally. In particular, for the evaluation of the production intensification level, the usage of the other resources should be taken into account as well.

The obvious example of this was the agriculture of the former USSR, the coal industry, peat extraction etc. It is known that in these fields, the whole gains were got on the grounds of the rise of the labor productivity. But saying that those fields were totally transitioned into the intensive form of the development at that time would not be correct. The self cost of the production unit in 1961-1980 became expensive by 30\% and some fields were working with losses.

\section{Ton Conditional Heating-Oil Equivalent}

For example: in 1980 the level of the common profitability was minus $7.5 \%$ in the coal industry. During 10 years repercussion of the foundation was decreased by $41 \%$.

The expenses of the material resources of the most important sorts on the product unit were increased. Only in 1980 the field overspent 71.5 million $\mathrm{KW} / \mathrm{H}$ electro energy in comparison to the planned indicator, etc. [4].

Based on the said above it becomes clear that the amount of the share of the labor productivity in the rise of the production cannot be a unique and exhaustive indicator in order to evaluate the extensive and intensive forms of the economic growth. It is obvious that it cannot be insignificant for the economy how all the other resources are utilized and first of all it is heating-energy.

The importance of the economy of the energy resources is particularly high in 
our country. It was so before and now. However, its role is much more today [5].

\section{Social Labour Productivity, Energy Efficiency and Kindness}

The analysis has shown that during the Soviet period, on the level of development of that time in conditions of Georgia, the economy of energetic resources was more important in some fields rather than the rise of the labor productivity: in particular, each percent of the economy of energy resources in comparison to the rise of the labor productivity in the same way, gave 1.3 times more effect in the black metallurgy. The calculation has shown that in 1988 net products of 815,000 Ruble could be got by the rise of the labor productivity by $1 \%$ in this field, however, in the conditions of saving $1 \%$ of the electro volume 106,900 Rubles were saved, which is $31.2 \%$ more [6].

The importance of the energy inclusive economy was risen even more during the years of Georgian independence. This was promoted by the conditions that the economics of the country became mainly dependant on the import of the energy resources. In 2000 in the industry of Georgia the reduction of the electro volume of the production by $1 \%$ was worth of GEL 18,500 cost production. When the increase of the labor productivity by the same level would mean the expanding of GEL 10,500 of the product (Table 1) [7].

\section{GEL National Currency 1US Dollars = GEL 2.45 (May 2018)}

Some macroeconomic figures of Georgia during the last 4 years are givenin the first table; the following calculations (Table 2) and the main conclusions in the article are based on them. The data of the Table 1 shows us that during the mentioned period the production of the Gross domestic product (GDP) was

Table 1. Some macro economical indicators of Georgia in 2013-2016 [8] [19].

\begin{tabular}{|c|c|c|c|c|c|c|}
\hline \multirow{2}{*}{ Indicators } & \multirow{2}{*}{$\begin{array}{l}\text { Measurement } \\
\text { unit }\end{array}$} & \multicolumn{4}{|c|}{ Years } & \multirow{2}{*}{$\begin{array}{c}\text { In } 2016 \\
\text { by } \% \text { to } \\
2013\end{array}$} \\
\hline & & 2013 & 2014 & 2015 & 2016 & \\
\hline $\begin{array}{c}\text { Gross domestic } \\
\text { product }(\mathrm{GPD}) \\
\text { constant by } 2010 \text { prices }\end{array}$ & million $\mathrm{GEL}^{1}$ & 26847.4 & 29150.5 & 31755.6 & 34028.5 & 126.7 \\
\hline $\begin{array}{c}\text { Last utilization of the } \\
\text { energy resources }\end{array}$ & $\begin{array}{l}1000 \text { tone } \\
\text { conditional } \\
\text { heating }\end{array}$ & 3726.3 & 4022.8 & 4174.6 & 4330.5 & 116.2 \\
\hline $\begin{array}{l}\text { Number of the } \\
\text { population }\end{array}$ & 1000 people & 4483.8 & 4490.5 & 3713.2 & 3720.4 & 83.0 \\
\hline Employed among them & 1000 people & 1712.1 & 1745.2 & 1779.9 & 1763.9 & 103.0 \\
\hline $\begin{array}{l}\text { The volume of the } \\
\text { energy product in GPD }\end{array}$ & Million GEL & 1075.6 & 1158.5 & 1147.0 & 1332.0 & 123.8 \\
\hline $\begin{array}{l}\text { The import of the } \\
\text { energy products }\end{array}$ & million USD & 1291.5 & 1127.1 & 1172.9 & 975.4 & 75.5 \\
\hline $\begin{array}{l}\text { The export of the energy } \\
\text { products }\end{array}$ & million USD & 65.9 & 3.1 & 129.8 & 62.3 & 94.5 \\
\hline
\end{tabular}


Table 2. The inter comparison of the importance of the social labour productivity and energy volume of theproduction in the economy of Georgia [6] [10] [19].

\begin{tabular}{|c|c|c|c|c|c|c|}
\hline \multirow{2}{*}{ Indicators } & \multirow{2}{*}{$\begin{array}{c}\text { Measurement } \\
\text { unit }\end{array}$} & \multicolumn{4}{|c|}{ Years } & \multirow{2}{*}{$\begin{array}{l}2016 \% \text { to } \\
2013\end{array}$} \\
\hline & & 2013 & 2014 & 2015 & 2016 & \\
\hline $\begin{array}{l}\text { The production of GDP } \\
\text { on } 1 \text { employee }\end{array}$ & GEL & 15681 & 16703 & 17841 & 19292 & 123.0 \\
\hline $\begin{array}{l}\text { Energy volume of GDP } \\
\text { in natural indicators }\end{array}$ & $\begin{array}{c}\mathrm{Kg} . \\
\text { conditional } \\
\text { heating/GEL }\end{array}$ & 0.139 & 0.138 & 0.131 & 0.127 & 91.4 \\
\hline $\begin{array}{l}\text { Energy volume of GDP } \\
\text { invaluable indicators }\end{array}$ & GEL & 0.118 & 0.109 & 0.108 & 0.106 & 89.8 \\
\hline $\begin{array}{c}\text { The meaning of lin GDP: } \\
\text { a) The rise of the labor } \\
\text { productivity }\end{array}$ & $\begin{array}{l}\text { Million } \\
\text { GEL }\end{array}$ & 267 & 290 & 256 & 429 & 160.6 \\
\hline $\begin{array}{l}\text { b) The reduction of } \\
\text { energy volume }\end{array}$ & $\begin{array}{l}\text { Million } \\
\text { GEL }\end{array}$ & 208 & 313 & 301 & 400 & 192.3 \\
\hline
\end{tabular}

increased by $26.7 \%$ and the final consumption of the energy resources by $16.2 \%$. The volume of the energy production in GDP was increased by $(23.8 \%)$ and the amount of employees in the economics by (30\%). Accordingly, the export-import of the energy products were reduced [9] [10].

The conducted analysis (Table 2) showed us that the production of GDP on a single employee (the productivity of the social labor) in Georgia during 2013-2016 was increased by $23 \%$. And the energy volume in the natural indicators was decreased by $8.6 \%$ in the cost indicator by $10.2 \%$. It's mentionable that during the years of independence of Georgia, so since 1991 till 2013 the fuel and energy balance was not developed at all for the entire country. First it was made in 2013.

The simple calculation confirmed that the conclusion made above about the role of importance of energy volume reduction in the real growth of GDP is still active today. In particular, during the 4 years of research the decrease of the energy volume by $1 \%$ increases the GDP by the same amount and in some years even by more than the increase of the labor productivity.

The meaning of the economy of energy resources as the source of the economic growth of the country, as it has already been said, is increasing more and more according to the scales of the production and its intensification. Its impact is especially big in the conditions of development of the market relationship [11].

Saving the energy reduces the demands, as for personally of oneself, the necessary expenses of the serving fields as well. At the same time it also enables us to reduce the financial investments on production of extraction of the raw materials and necessary equipment for extraction industry. The saved expenses can be used for development of production of consumables and the people service field, for the improvement of the level of living of inhabitants [12]. 


\section{Increasing of Energy-Producing or Energy-Efficiency?}

It is known that the conduction of the heating-energy resources, as well as their extraction needs particular expenses. Therefore, there is a question: is it better to care about the expanding the production of the energy resources instead of its economy?

It is obvious that the expanded reproductive process requires creation of the new energy powers. However, the answer cannot be positive particularly here. Firstly, even if the supplies of the heating-energy resources are not limited, the mentioned opinion is not justified in the view of economy. The research shows that the measures used for the economy of heating-energy resources give us quite an effective result. Using small expenses it becomes possible to save quite a lot of heating-energy resources and the extraction of its equivalent amount would need much more expenses. It is proved that in comparison to the extraction of the equivalent amount of the heating and the expenses used for production of the energy in order to economize the heating-energy resources, the conduction of the high scale measures needs 2 - 3 times less money on average [13] [14].

Secondly, the practice shows us that the increase of the heating-energy resources not only reduces, but on a contrary, aggravates the deficit of these resources as well as of other resources. As it has already been mentioned, this is caused by the circumstances that the extracting industry is a more capital capacious, fund capacious and labor capacious field, and a significant number of machines and equipment, materials and energy are necessary for its development. The demands of the economy on these resources are increasing rapidly and its satisfaction by only an extensive way is not only effective, but also impossible [15] [16].

The economic and rational usage of the energy resources has an especially big importance for our country. It is enough to say that some kinds of fossils (coal etc.) the significant number of the heating-energy resources (oil, natural gas, oil products), wood etc. are imported to Georgia from a long distance of the outer countries. Also, its import expenses are quite high. And the losses on the transportation are high as well [17].

In the near past of Georgia (the $90^{\text {th }}$ ) the consumption of the heating-energy resources, 2.180 million $\mathrm{KW} / \mathrm{H}$ electro energy was saved by $1 \%$ economy: over 20 tons of conditional heating amount coal: up to 52 thousand gas and almost the same amount of black oil: 200 thousand giga calories on the heating-energy. Using the named resources it could be possible to prepare: 600 million units of red bricks, i.e. much more than Georgia totally produced, or 1.5 million tons of bread and bakery products. The indicated amount of the electro energy was enough for preparation of 250 thousand of paper or 1.3 million tons of cement, 4 million units of silicate bricks, 200 million pairs of shoes or 1.8 million tons of sausages and so on [18].

The rational usage of the energetic resources also has a big economic and so- 
cial importance in life. Their sensible and correct usage reduces the losses in the household agriculture and it is a significant source for the improvement of the level of the household life. Thrift and economy in the everyday life is a good additional income, not only for the budget of the family but for the whole society as well. Today, approximately 1.6 billon $\mathrm{KW} / \mathrm{H}$ electro energy is consumed in the household sector of Georgia annually. It is 40 times more energy than the amount which our large hydro power plants: Khram HPP, Shaor HPP and Jinval HPP can produce together. 15 million KW/H energy could be saved only by $1 \%$ of its economy [19].

\section{References}

[1] Chomakhidze, D. (2016) Energy Balance of Georgia Sciencedirect. Analyses of Agrarian Science, 14, 13.

[2] National Statistics Office of Georgia (Geostat) (2016) Energy Balance of Georgia 2016. Statistical Publication, p. 49.

[3] Chomakhidze, D. and Shengelia, G. (2017) Energy Complex of Georgia. Lap, Lambert Academic Publishing, p. 63.

[4] Gitelman, L.D. and Ratnikov, V.E. (2008) Energetical Business. M. (In Russian)

[5] Chomakhidze, D. (2000) Georgian Energy Security. PDP. Tbilisi., p. 505. (In Georgia)

[6] Georgian National Energy and Water Supply Regulation Commission. Annual Reports 2000-2016. http://www.gnerc.org/

[7] Georgian Energy Market Operator (ESCO), Annual Reports 2006-2016, http://www.esco.ge/

[8] Chomakhidze, D. (2014) Energy Sector of Georgia. Technical University, Tbilisi. (In Georgian)

[9] Chomakhidze, D. (2007) Georgia Energy Resources. Central Asia and the Caucasus, $4(45)$.

[10] Statistical Yearbook of Georgia, GEOSTAT, 2016.

[11] Papava, V. (2015) Economy of Georia. Reformal and Pseudo-Reformal. Tbilisi. 235.

[12] Gvelesiani, T. and Chomakhidze, D. (2011) Georgian Energy Security (Hidroecological and Economical Problems of Engeneering) Tbilisi. 468.

[13] Chomakhidze, D. (2012) Energy Sector and Society. Tbilisi. 114.

[14] Samsonia, N., Chomakhidze, D. and Gulashvili, M. (2017) Economics and Management of Energy Sector. Tbilisi. 250.

[15] Asatiani, R., Chitanava, N., Papava, V., Meskhia, I. and Chomakhidze, D. (2012) Economics of Georgia. Tbilisi. 307.

[16] Chitanava, N. (2015) The Problems of Georgia. Annals of Agrarian, 13.

[17] Chomakhidze, D. and Kublashvili, G. (2017) Renewable Energy Resources of Georgia. Tbilisi. 72. (In Georgian)

[18] Chomakhidze, D. (2007) Energy Balance of Georgia 2007. Tbilisi. 230.

[19] http://www.geostat.ge 